\title{
INTEREST IN ENVIRONMENTAL ISSUES AS A DETERMINANT OF SCIENCE LITERACY: A MULTINATIONAL REVIEW WITH ARTIFICIAL NEURAL NETWORK ANALYSIS
}

\author{
Umut Birkan Özkan* \\ National Defence University, Turkey
}

\begin{abstract}
This study uses PISA 2018 data to analyze, from a multinational perspective, whether interest in environmental issues is a determining factor of science literacy. A relational survey model is used as a quantitative research design to analyze secondary data obtained from the PISA 2018 evaluation data of 98,306 students at the age of 15 in 15 different countries and economies. Several statistical tests, including t-test, multiple regression analysis, and artificial neural network analysis are employed. According to the results of the analysis, significant differences are found between the science literacy scores of students who are very interested' in the environmental issues in their country and those who are not at all interested. Similarly, significant differences are found between the science literacy scores of students who are 'very interested' in environmental issues in other countries and those who are not at all interested. In addition, students' relevance to environmental problems are factors that statistically predict students' science literacy in a significant way.
\end{abstract}

Keywords: environmental issues, science literacy, PISA 2018, large scale assessment, artificial neural network analysis

\section{Introduction}

Environmental issues are a global topic area that concerns all countries. Environmental issues have been on the agenda of countries for many years. Whether or not one has a responsible attitude towards the environment is an international concern, and it is also of economic importance for countries (Thomson \& De Bortoli, 2008). It can be said that factors such as the decrease of the arable lands in the world, pollution of groundwater and

*Correspondence: uozkan@msu.edu.tr 
surface water and being close to extinction in forests, fisheries and oil resources have an important effect on the view of countries about environmental issues (Wilson, 2002). All of these open up environmental issues to debate, and against the environmental problems which are getting more and more complicated, countries are obliged to face the need to develop an understanding in their citizens to deal with environmental issues (Bybee, 2008). The fact that individuals do not have sufficient understanding about basic environmental issues is often seen as a cause of environmental destruction (Schneider, 1997).

In addition to the need of individuals who are interested in environmental issues, it can be said that countries also need individuals who are successful in the field of science in order to create the scientific staff they will need in conducting scientific research and producing technological innovations (Areepattamannil \& Kaur, 2013; Organisation for Economic Co-operation and Development [OECD], 2013). It is important to provide good science education in schools so that countries can achieve this. According to Susongko \& Afrizal (2018), one of the most important goals in a good science education is for students to reach scientific literacy. Holbrook \& Rannikmae (2009) define increasing science literacy through science education as developing the ability to use appropriate evidence-based scientific knowledge and skills creatively, especially in relation to daily life and professional career. The fact that science literacy was determined to be the main focus subject in the 2015 and 2006 implementations of Programme for International Student Assessment (PISA), which is supported by the OECD and which offers opportunity to evaluate countries' and economies' education systems on an international platform (OECD, 2016), can be considered as an indicator of the importance given to science literacy globally. In the PISA 2018 evaluation, which emphasizes the application of science literacy and scientific knowledge in the context of real world situations, "environment" is one of the content areas used in cognitive test questions within the scope of science literacy (OECD, 2019a). In other words, real-world applications of environmental issues are evaluated within the scope of science literacy.

In general, environmental issues are associated with science lessons. According to Littledyke (2008), science education plays an important role in understanding the concepts that support environmental problems with scientific evidence and pave the way for environmental protection behaviors. There are several studies in the literature suggesting that environmental issues are related to the individual's science literacy (Areepattamannil \& Kaur, 2013; Bybee, 2008; Kaya \& Elster, 2018; OECD, 2006). OECD (2006) expresses the students' responsibility for the environment, their general appreciation, attitudes towards science issues, as one of the areas that constitute their perspective on science-related issues. Bybee (2008) argues that individuals with science literacy are more knowledgeable about environmental issues. According to Areepattamannil \& Kaur (2013), one of the individual level factors affecting science success is students' awareness and perceptions about environmental issues. Kaya \& Elster (2018) state that science literacy, which is of great importance for PISA, contains items related to environmental issues. All these views reveal that although science literacy involves many topics, environmental issues have an important role in developing science literacy. In this context, a multinational study investigating whether students' interest in environmental issues in real life is an effective factor in improving science literacy may be an important research objective.

The vision of science literacy, which emphasizes students' ability to use science in real life contexts, calls for comparisons in science education (Sadler \& Zeidler, 2009). In this regard, comparing the science literacy scores of students who are interested in environmental issues in real life with that of those who are not interested is important for understanding the 
impact of interest in environmental issues on science literacy. In addition, the young population's interest in environmental issues and the level of science literacy may have an impact on the country's more livability and international competitiveness in tomorrow's high-tech industry. Considering the importance of being interested in environmental issues and science literacy, it can be said that it is important to examine the effect of students' interest in environmental issues on science achievement.

\section{Research Questions}

In this study, it is aimed to examine, from a multinational perspective, whether interest in environmental problems is a determining factor on science literacy. For this purpose, questions, answers of which are sought, are these:

1) Is there a significant difference between the science literacy scores of students who are interested in environmental problems and that of those who are not interested?

2) Is interest in environmental problems a significant predictor of science literacy?

\section{Method}

In this study, which used a relational survey model, which is a quantitative research model, the secondary data obtained from the PISA 2018 evaluation were analyzed. It can be said that the analysis of the secondary data is a research method that applies the same basic research principles as the studies using the primary data and has some steps to be followed (Johnston, 2017). Analysis using secondary data can be defined as an analysis of an existing database in order to review the literature, to answer unique research questions with different research methods, or to answer new questions with old data (Turner, 1997). Researchers can use secondary data to answer new research questions, support / expand original analysis, or compare with other (primary or secondary) data sources (McGinn, 2008). This data can provide researchers with resources to examine and analyze new hypotheses, to learn about research questions apart from the original data collection goal, and to obtain new and / or additional comments and conclusions that are not found in the original research findings (Sherif, 2018). The reason why this method was preferred in this research was that the analysis made with the secondary data could be used to make comparative analysis in different contexts, in different time periods and between different social groups and cultures (Corti, 2008).

\section{Sample}

The data of this study were obtained from the target population, which includes students aged 15 in 15 participating countries and economies who responded to the questions "How interested are you in the following issues Environmental issues in your country \& Environmental issues in other countries" in the PISA 2018 assessment. The student sample was decided by the National Project Managers (NPMs) to ensure the representation of the full target population of 15 -year-old students in the participating countries and economies and by maintaining PISA-related quality standards (For more information about the sampling method, see https://www.oecd.org/pisa/data/pisa2018technicalreport/). PISA 2018 sampling design is a two-stage stratified sampling design for every country except Russia, which is outside the scope of this study. At the first stage, at least 150 school samples were selected by taking the factors such as school location and education level (lower secondary or upper secondary school) into account, and in the second stage, approximately 
42 students aged 15 were selected from these schools (OECD, 2019b). The numbers related to the sample set used in this study, representing the participating countries and economies in the PISA 2018 evaluation, are presented in Table 1.

Table 1.

Sampling of the Countries and Economies in the Study

\begin{tabular}{|c|c|c|c|}
\hline $\begin{array}{l}\text { Countries } \\
\text { and } \\
\text { economies }\end{array}$ & $\begin{array}{l}\text { Number of } \\
\text { Samples }\end{array}$ & $\begin{array}{l}\text { Numbers of students } \\
\text { answering the question: "How } \\
\text { interested are you in the } \\
\text { following issues? } \\
\text { Environmental issues in your } \\
\text { country" }\end{array}$ & $\begin{array}{l}\text { Numbers of students } \\
\text { answering the question: } \\
\text { "How interested are you in } \\
\text { the following issues? } \\
\text { Environmental issues in other } \\
\text { countries" }\end{array}$ \\
\hline Brazil & 10691 & 8564 & 8435 \\
\hline Chile & 7621 & 6791 & 6787 \\
\hline Croatia & 6609 & 5643 & 5635 \\
\hline $\begin{array}{l}\text { Dominican } \\
\text { Republic }\end{array}$ & 5674 & 5268 & 5266 \\
\hline Georgia & 5572 & 5280 & 5225 \\
\hline Germany & 5451 & 2551 & 2545 \\
\hline Hong Kong & 6037 & 5450 & 5447 \\
\hline Ireland & 5577 & 4907 & 4899 \\
\hline Italy & 11785 & 9869 & 9852 \\
\hline Korea & 6650 & 6504 & 6479 \\
\hline Мacao & 3775 & 3678 & 3665 \\
\hline Malta & 3363 & 2640 & 2642 \\
\hline Mexico & 7299 & 6848 & 6838 \\
\hline Panama & 6270 & 4722 & 4690 \\
\hline Portugal & 5932 & 5334 & 5320 \\
\hline Total & 98306 & 84049 & 83725 \\
\hline
\end{tabular}

When Table 1 is examined, it is seen that all 98306 students could not be included in the study since some of the students left the questions "How interested are you in the following issues? Environmental issues in your country \& Environmental issues in other countries" blank. The group included in the study can be accepted as a simple random sampling of the sample, since the data of the students excluded from the study are not related to the values of the other students in the sample and this situation is meaningful for all students in the sample (Allison, 2002).

\section{Instrument}

The data of this study were obtained from the students' scores from the science literacy test applied in the PISA 2018 study and their answers to the student survey questions. Scientific literacy in PISA is defined as "the ability to engage with science-related issues, and with the ideas of science, as a reflective citizen" (OECD, 2019a, p. 15). The scientific literacy assessment in PISA 2018 "tests student ability at three different levels of cognitive demand" (low, medium, high cognitive demands) (Thomson et al., 2019, p. 27). Science items in PISA 2018 assessment designed "to measure students' capabilities to explain phenomena scientifically, evaluate and design scientific enquiry, and interpret data and evidence scientifically" (OECD, 2019a, p. 100). Scientific knowledge includes "content 
knowledge (the content of science, which accounted for $54 \%-66 \%$ of the total test items), procedural knowledge (the knowledge of the procedures that scientists use to establish scientific knowledge, which accounted for $19 \%-31 \%$ of the total test items), and epistemic knowledge (an understanding of the rationale for the common practices of scientific inquiry, the status of the claims that are generated, and the meaning of foundational terms such as theory, hypothesis and data, which accounted for $10 \%-22 \%$ of the total test items)" (Ma \& Qin, 2021, p. 7).

PISA 2018 has determined ten plausible values for each participant student as an indicator of science literacy. The potential value methodology uses efficiency distributions and takes error at the individual level into account, using efficiency values with multi equals instead of assuming zero uncertainty (OECD, 2017). Therefore, ten plausible value estimations are made independently for each student. Using any of these 10 values or using the average of these 10 values may cause the standard error to be smaller than normal (Rutkowski et al., 2010). OECD (2009) recommends using all of these plausible values for each student in studies using PISA data. For the reasons explained, in this study, all plausible values are included in the analysis.

In PISA 2018, questions in the student questionnaire are used to define the characteristics of students that affect science literacy. In this study, the questions coded PA169Q03HA and PA169Q04HA were used to examine the determining role of students' interest in environmental issues on science literacy. The question with the code of PA 169Q03HA is: How interested are you in the following issues? Environmental issues in your country. The question with the code of PA 169Q04HA is: How interested are you in the following issues? Environmental issues in other countries'. For these questions, students were asked to choose one of the options "not interested at all", "not very interested", "somewhat interested", "very interested".

\section{Data Analysis}

In this study, for students of 15 different countries and economies, the determining role of being related to environmental issues on science literacy was analyzed. In this study, firstly, independent samples t-test was used to examine whether there is a significant difference between the scores of students who are very interested in environmental issues and students who are not interested at all to environmental issues. In the next step of the research process, multiple regression analyzes were conducted using the science literacy scores as dependent variables and students' preferences to be interested in environmental issues as independent variables. IEA International Database Analyzer Version 4.0.35 (IDB Analyzer) software was used to perform multiple regression analysis and t-test. IDB Analyzer was developed to analyze large-scale assessments. IDB Analyzer can perform statistical analysis taking sampling design, sampling weights and plausible values into account. Considering the unique structure of PISA, IDB Analyzer can analyze multiple regression and calculate regression coefficients for independent variables that predict dependent variables with 10 different plausible values. Therefore; in this study, where large scale evaluation data was used, IDB Analyzer was applied to obtain reliable results.

The dummy variables required to analyze the effect of the classified variables on the dependent variable are automatically generated by the IDB Analyzer program. IDB Analyzer provides appropriate tools to estimate the coefficients and sampling errors that reflect the sample design, and it can be said that assumptions about multiple regression (normality, multicollinearity) need to be verified (Mirazchiyski, 2014). Since the data of over 80 thousand participants were analyzed in this study, it can be accepted that the distribution is normal. 
The study of Lumley et al. (2002) shows that normal distribution assumption is not required in sufficiently large samples. In addition, both the 'law of large numbers' and the "central limit theorem" mechanisms work for large samples. Because the sample mean of a large number of observations will be close to the average, or even if the observations themselves do not have a normal distribution, they will show a distribution close to normal (Shatskikh \& Melkumova, 2016). Correlation matrix performed to check whether there are multiple connectivity problems between the predictive variables is given in Table 2 .

Table 2.

Correlation Matrix between Predictive Variables

\begin{tabular}{|c|c|c|}
\hline Countries and economies & Variables & PA 169Q04HA \\
\hline Brazil & & .57 \\
\hline Chile & & .63 \\
\hline Croatia & & .65 \\
\hline Dominican Republic & & .46 \\
\hline Georgia & & .49 \\
\hline Germany & & .68 \\
\hline Hong Kong & & .67 \\
\hline Ireland & PA169Q03HA & .67 \\
\hline Italy & & .62 \\
\hline Korea & & .59 \\
\hline Macao & & .55 \\
\hline Malta & & .55 \\
\hline Mexico & & .59 \\
\hline Panama & & .49 \\
\hline Portugal & & .65 \\
\hline
\end{tabular}

According to the values given in Table 2, it can be argued that there is no multicollinearity problem among the predictor variables of this study since the mutual correlations between the predictive variables do not exceed the recommended limit of 0.80 in the literature (Kim, 2019; Midi et al., 2010).

In this study, the order of importance of independent variables in multiple linear regression analysis was determined by Artificial Neural Network (ANN) analysis and compared with the results obtained from multiple linear regression analysis. Having been inspired by the human brain neural network, ANN is considered a mathematical model that stands for a substantially parallel and distributed processing system (Greenwood, 1991; Haykin 1999; Haykin, 2009; Pektas, 2013). In biological systems, learning incorporates modifications to the synaptic connections occurring between the neurones. The neural network approach was initially introduced to act like the human brain in solving problems. The novelty of this approach lies in its way of processing information (Greenwood, 1991). An ANN model comprises massive numbers of processing elements (neurones) that are interconnected and work together to solve sophisticated problems (Haykin, 1999). Among the three models of computer-based learning, namely supervised learning, unsupervised learning and reinforcement learning, an ANN model can be identified as supervised learning, since learning occurs depending on pre-existing examples known as training data. An ANN 
can be constructed for pattern recognition, data classification, and/or training and learning treatments.

As presented in Figure 1, an ANN model is composed of three layers of input, hidden and output. The hidden nodes is the layer where the inputs of $\mathrm{x} 1, \mathrm{x} 2, \ldots, \mathrm{xn}$ are processed and the output yk is released.

Figure 1.

Sample ANN model

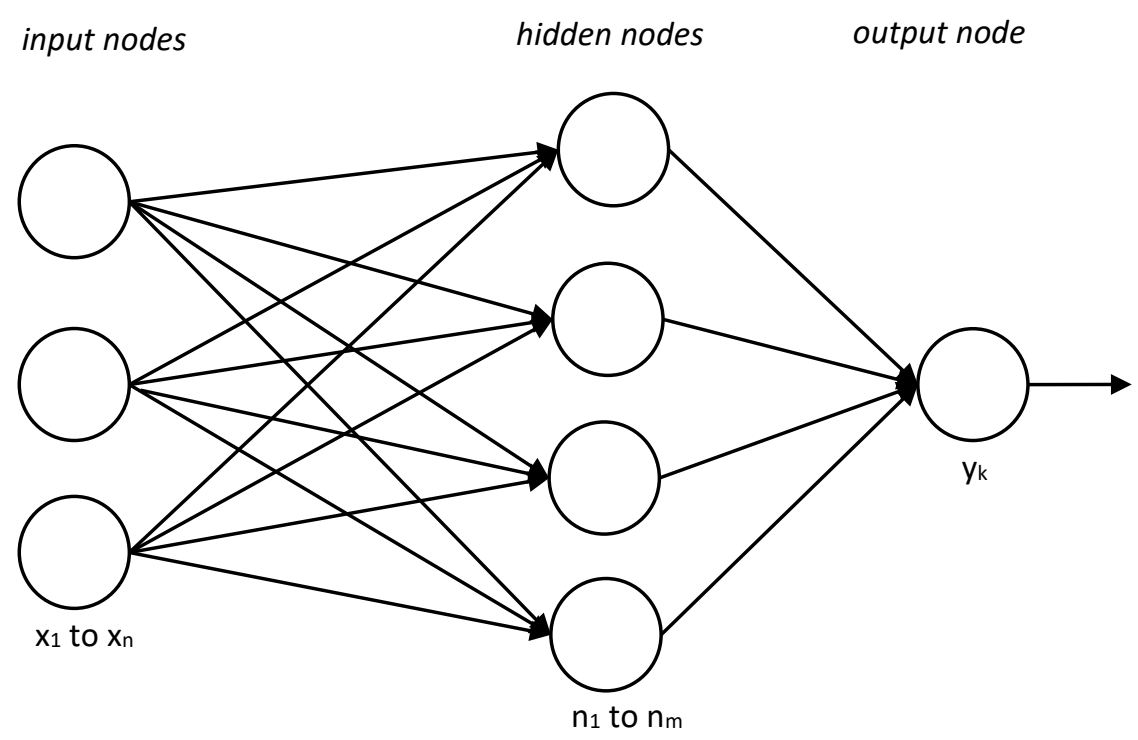

Owing to its computational power and the ability to process various types of data, the ANN model is utilized in various fields of information systems such as e-learning (Scott \& Walczak, 2009; Shmueli \& Koppius, 2011). Considered as non-parametric based models, the ANN models suggest diverse advantages with no consideration for distribution of input data, but with a strength of capturing linear and nonlinear relationships. Conversely, parametric based models hold certain concerns about distribution of given data (Hair et al., 2010).

During ANN analysis, students' science literacy scores was taken as the output variable, also called the output layer, which corresponds to dependent variable in statistics. The predictive variables are students' preferences to be interested in environmental issues. All the variables in the model were undergone a transformation of "normalized". In the partition of data set, random cases were assigned in accordance with relative case number. The present data were classified as training data, testing data, and validation data. No specific method exists in the classification of data. According to Zhang et al., (1998), data are frequently classified as $80 \%$ training and $20 \%$ testing or $70 \%$ training and $30 \%$ testing. In this study, the rates were defined as 60\% training data, 30\% testing data and $10 \%$ validation data. The reason for using $10 \%$ verification data in this study is that overfitting, which is a condition to be considered in machine learning, such as ANN, can be prevented. In this study, which uses a large data set, 60\% training data, 30\% testing data, 10\% holdout data are divided into both the training data and the holdout data feature, which can be used in the latest versions of the SPSS program, to prevent overfitting. Thus, the training-test-verification set triplets were created and the model was run on more data and measures were taken for overfitting. 
IBM SPSS Statistic 22 pack was utilized during analyses, where the architecture of the ANN model was automatically designed. With the selection of automatic architecture, hyperbolic tangent function was identified as the interlayer activation function and identity function was selected for the output layer. In automatic architecture selection option, number of hidden layers is chosen as 1. Literature reveals frequent use of 3-layered network structures with one hidden layer (Han \& Wang, 2011; Hippert et al., 200 1; Zhang et al., 1998). In ANN analysis, online learning was preferred as the learning method. The existence of interdependence of analysis data was the rationale behind this selection.

\section{Results}

\section{Results for the First Research Question}

The first research question aims to determine whether there is a significant difference between the science literacy scores of students who are interested in environmental problems and that of those who are not interested. The results of the t-test conducted to determine whether there are significant differences between the science literacy scores of students who are not interested in environmental problems in their country and who are very interested in it, are presented in Table 3.

Table 3.

" $t$ " Values for Science Literacy Scores in Terms of Interest in Environmental Problems in the Country

\begin{tabular}{|c|c|c|c|c|}
\hline \multirow[b]{2}{*}{$\begin{array}{l}\text { Countries and } \\
\text { economies }\end{array}$} & \multicolumn{2}{|l|}{ Average Point } & \multirow[b]{2}{*}{ t value } & \multirow[b]{2}{*}{$\begin{array}{l}\text { Effect Size } \\
\text { (Cohen's d) }\end{array}$} \\
\hline & $\begin{array}{l}\text { Not interested at } \\
\text { all }\end{array}$ & Very interested & & \\
\hline Brazil & 378.39 & 421.89 & $7.52^{* *}$ & .49 \\
\hline Chile & 392.34 & 457.07 & $8.95^{* *}$ & .81 \\
\hline Croatia & 432.34 & 489.26 & $6.39^{* *}$ & .69 \\
\hline Dominican Republic & 305.98 & 341.69 & $6.78^{* * *}$ & .53 \\
\hline Georgia & 319.89 & 394.58 & $9.77^{\text {*** }}$ & .99 \\
\hline Germany & 482.88 & 542.01 & $2.79^{* *}$ & .60 \\
\hline Hong Kong & 505.22 & 527.43 & $2.70^{* * *}$ & .26 \\
\hline Ireland & 447.99 & 510.09 & $7.08^{* * *}$ & .72 \\
\hline Italy & 427.42 & 484.02 & $4.71^{* * *}$ & .65 \\
\hline Korea & 428.56 & 530.86 & $5.13^{* * *}$ & 1.06 \\
\hline Macao & 501.41 & 549.97 & $5.68^{* *}$ & .60 \\
\hline Malta & 422.31 & 483.19 & $4.87^{* *}$ & .60 \\
\hline Mexico & 386.02 & 430.73 & $6.72^{* * *}$ & .61 \\
\hline Panama & 311.03 & 372.73 & $6.77^{\text {*** }}$ & .74 \\
\hline Portugal & 423.81 & 508.68 & $4.93^{* *}$ & .97 \\
\hline
\end{tabular}

** $t$ value is significant at the 0.01 level.

As shown in Table 3, in all countries and economies included in the study, it was found that there were significant differences between the science literacy scores of students who were not interested in environmental problems in their country and who were very interested in them. It can be stated that the effect size of the differences found is high for Chile, Georgia, Korea, Portugal, medium for Brazil, Croatia, Dominican Republic, Germany, Ireland, Italy, Macao, Malta, Mexico, Panama, and low for Hong Kong (Cohen, 1988). The results of the ttest carried out in order to determine whether there are significant differences between the 
science literacy scores of the students who are not interested in environmental problems in other countries and who are very interested in them are presented in Table 4.

\section{Table 4.}

"t" Values for Science Literacy Ccores in Terms of Interest in Environmental Problems in other Countries and Economies

\begin{tabular}{|c|c|c|c|c|}
\hline \multirow[b]{2}{*}{$\begin{array}{l}\text { Countries and } \\
\text { economies }\end{array}$} & \multicolumn{2}{|l|}{ Average Point } & \multirow[b]{2}{*}{$\mathrm{t}$ value } & \multirow[b]{2}{*}{$\begin{array}{l}\text { Effect Size } \\
\text { (Cohen's d) }\end{array}$} \\
\hline & $\begin{array}{l}\text { Not interested at } \\
\text { all }\end{array}$ & Very interested & & \\
\hline Brazil & 383.46 & 429.80 & $8.17^{* * *}$ & .52 \\
\hline Chile & 416.94 & 464.93 & $9.68^{* *}$ & .61 \\
\hline Croatia & 437.19 & 497.11 & $8.40^{* *}$ & .68 \\
\hline Dominican Republic & 318.78 & 339.62 & $4.58^{* *}$ & .31 \\
\hline Georgia & 359.32 & 392.93 & $4.87^{* * *}$ & .41 \\
\hline Germany & 466.80 & 550.06 & $7.39^{* * *}$ & .88 \\
\hline Hong Kong & 505.46 & 518.44 & 1.57 & .15 \\
\hline Ireland & 461.56 & 517.93 & $9.08^{* *}$ & .66 \\
\hline Italy & 436.24 & 491.94 & $7.79^{* *}$ & .64 \\
\hline Korea & 462.68 & 533.89 & $6.39^{\text {** }}$ & .75 \\
\hline Macao & 518.90 & 548.40 & $4.15^{* *}$ & .35 \\
\hline Malta & 431.58 & 498.40 & $7.27^{* *}$ & .64 \\
\hline Mexico & 399.23 & 432.78 & $6.43^{* *}$ & .45 \\
\hline Panama & 333.27 & 379.81 & $6.23^{* *}$ & .55 \\
\hline Portugal & 435.98 & 517.19 & $9.39^{* *}$ & .92 \\
\hline
\end{tabular}

${ }^{* *}$ t value is significant at the 0.01 level.

As shown in Table 4, in Macao and countries other than Hong Kong, it was found that there were significant differences between the science literacy scores of students who had no interest in environmental problems in other countries and who were very interested in them. It can be stated that the effect size of the differences found is high for Germany, Portugal, medium for Brazil, Chile, Georgia, Croatia, Ireland, Italy, Korea, Malta, Mexico, Panama, and low for Dominican Republic, Macao (Cohen, 1988).

\section{Results for the Second Research Question}

The second research question aimed to determine the predictability of students' interest towards environmental problems on science literacy. Multiple linear regression analysis was performed to answer this research question. In Table 5, the model summary of the regression analysis and the results of the regression coefficients are given.

The multiple regression analysis results presented in Table 5 revealed that students' interest status variables explained $3 \%\left(\mathrm{R}^{2}=.03\right)$ of the variation in science literacy scores. According to Table 6, the predictor role of all independent variables is statistically significant. Students who are interested in environmental problems in their home country and other countries have higher science literacy scores than students who have no interest. According to Table 5, a student who is very interested in environmental problems in his own country has a science literacy score of 31.50 points higher than a student who is not interested at all. The fact that a student is very interested in environmental problems in other countries contributes 35.79 points to the science literacy score, compared to a student who is not interested at all. 
Table 5.

Regression Analysis Model Summary

\begin{tabular}{|c|c|c|c|c|c|}
\hline \multirow{3}{*}{ Model } & & \multirow{2}{*}{\multicolumn{3}{|c|}{$\begin{array}{l}\text { Adjusted } \mathrm{R}^{2}=.03 \\
\mathrm{~F} \text { change }=517.85 \\
\mathrm{p}<.01 \\
\text { Coefficients }\end{array}$}} & \\
\hline & & & & & \\
\hline & & B & Std. Error & $\operatorname{Beta}(\beta)$ & \\
\hline (Constant) & & 407.80 & 3.02 & & $135.15^{* *}$ \\
\hline \multirow{3}{*}{$\begin{array}{l}\text { Environmental } \\
\text { issues in other } \\
\text { countries }\end{array}$} & Not very interested & 19.70 & 2.05 & .09 & $9.62^{* *}$ \\
\hline & Somewhat interested & 29.13 & 2.05 & .16 & $14.23^{* *}$ \\
\hline & Very interested & 35.79 & 2.32 & .16 & $15.45^{* * *}$ \\
\hline \multirow{3}{*}{$\begin{array}{l}\text { Environmental } \\
\text { issues in your } \\
\text { country }\end{array}$} & Not very interested & 14.16 & 3.56 & .04 & $3.98^{* *}$ \\
\hline & Somewhat interested & 24.15 & 3.46 & .14 & $6.97^{* *}$ \\
\hline & Very interested & 31.50 & 3.58 & .17 & $8.80^{* *}$ \\
\hline
\end{tabular}

** $t$ value is significant at the 0.01 level.

ANN analysis was used in addition to multiple linear regression analysis in the analysis of the data. First, the order of significance of the predictability of the students' interest status of environmental issues in their home country on science literacy scores was determined by ANN analysis. The run summary of data included to ANN analysis is presented in Table 6.

Table 6.

ANN Data Run Summary for Students' Interest Status of Environmental Issues in their Country on Science Literacy Scores

\begin{tabular}{lll}
\hline & $\mathrm{N}$ & $\%$ \\
\hline Training data & 50008 & $60.2 \%$ \\
Testing data & 24834 & $29.9 \%$ \\
Validation data & 8291 & $10 \%$ \\
Valid data & 83133 & $100 \%$ \\
Excluded data & 0 & \\
Total & 83133 & \\
\hline
\end{tabular}

Table 6 shows that the whole data set was split into training $(60.2 \%, \mathrm{n}=50008)$, testing $(29.9 \%, \mathrm{n}=24834)$ and validation $(10 \%, \mathrm{n}=8291)$. All data used were valid, no data were excluded. The structure of the established ANN model and the neural networks are presented in Figure 2.

The weights of independent variables in the artificial neural network can be seen in Figure 2. To determine the ratings of independent variables' (students' interest status of environmental issues in their home country) importance, in accordance with the weights linking the artificial neural cells in the network, the ratings were defined in percentages and are presented in Table 7. 
Figure 2.

ANN Model Structure for Students' Interest Status of Environmental Issues in their Home Country on Science Literacy Scores

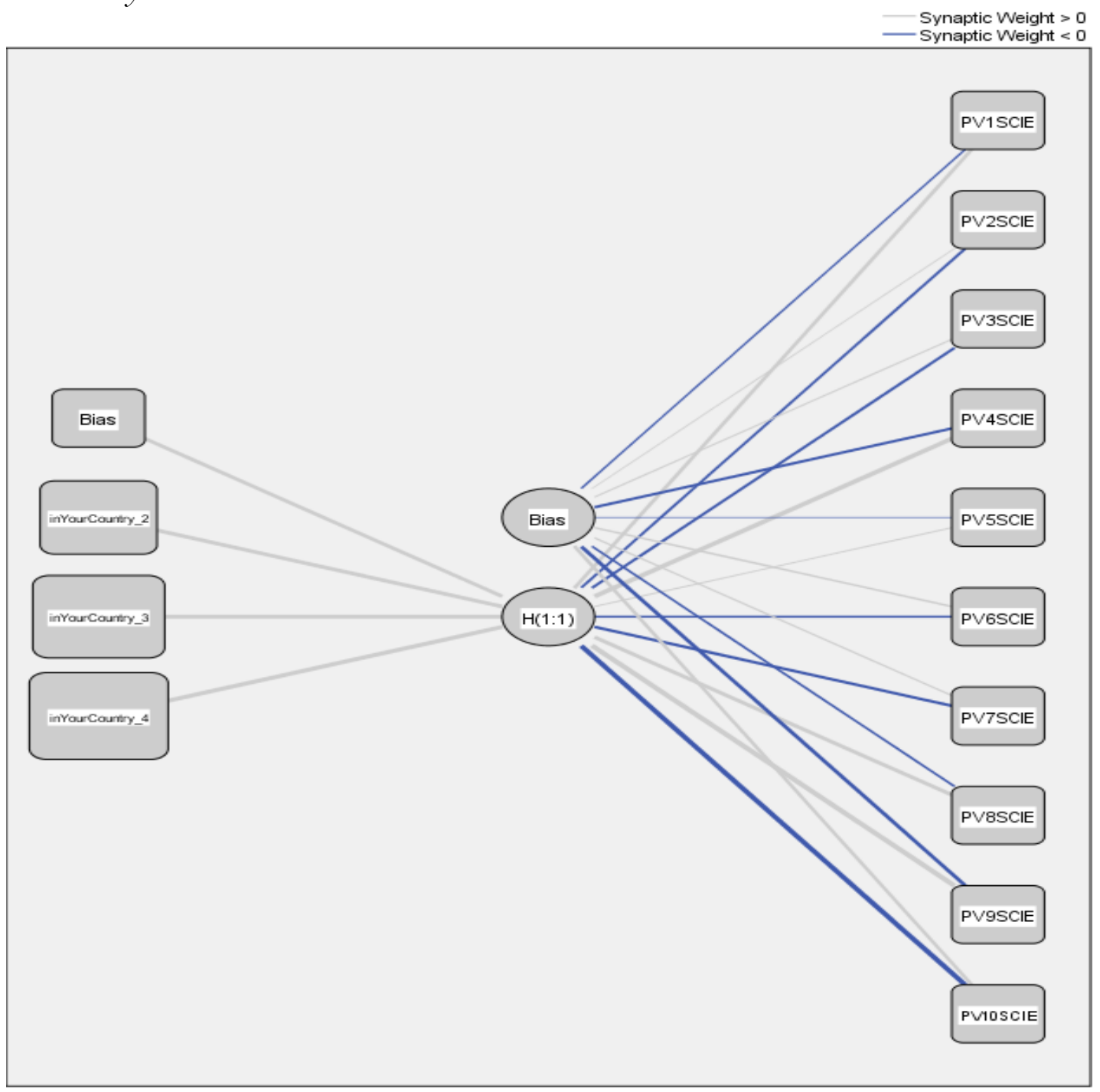

Table 7.

The Importance Ratings of Independent Variables (Students' Interest Status of Environmental Issues in their Home Country) Related to Atudents' Science Literacy Scores

\begin{tabular}{lll}
\hline & Importance & Normalized Importance \\
\hline Not very interested & .284 & $76.4 \%$ \\
Somewhat interested & .344 & $92.6 \%$ \\
Very interested & .372 & $100 \%$ \\
\hline
\end{tabular}

The values in Table 7 show that to be very interested in environmental issues in their home country as the most important independent variable in the ANN structured for students' science literacy scores. The other variables following this independent variable are "to be somewhat interested (92.6\%)", and "to be not very interested (76.4\%)". The importance order obtained from ANN analysis where students' interest status of environmental issues in 
their home country are used as independent variables (Table 7) and the order of importance obtained from multiple linear regression analysis (Table 5) are consistent with each other.

Second, the order of significance of the predictability of the students' interest status of environmental issues in other country on science literacy scores was determined by ANN analysis. The run summary of data included to ANN analysis is presented in Table 8.

Table 8.

ANN Data Run Summary for Students' Interest Status of Environmental Issues in Other Country on Science Literacy Scores

\begin{tabular}{lll}
\hline & $\mathrm{N}$ & $\%$ \\
\hline Training data & 50096 & $60.3 \%$ \\
Testing data & 24619 & $29.6 \%$ \\
Validation data & 8418 & $10.1 \%$ \\
Valid data & 83133 & $100 \%$ \\
Excluded data & 0 & \\
Total & 83133 & \\
\hline
\end{tabular}

Table 8 shows that the whole data set was split into training $(60.3 \%, \mathrm{n}=50096)$, testing $(29.6 \%, \mathrm{n}=24619)$ and validation $(10.1 \%, \mathrm{n}=8418)$. All data used were valid, no data were excluded. The structure of the established ANN model and the neural networks are presented in Figure 3.

The weights of independent variables in the artificial neural network can be seen in Figure 3. To determine the ratings of independent variables' (students' interest status of environmental issues in other country) importance, in accordance with the weights linking the artificial neural cells in the network, the ratings were defined in percentages and are presented in Table 9.

The values in Table 10 show that to be very interested in environmental issues in other country as the most important independent variable in the ANN structured for students' science literacy scores. The other variables following this independent variable are "to be somewhat interested (89.4\%)", and "to be not very interested (63\%)". The importance order obtained from ANN analysis where students' interest status of environmental issues in other country are used as independent variables (Table 9) and the order of importance obtained from multiple linear regression analysis (Table 5) are consistent with each other.

\section{Discussions and Recommendations}

In this study, by using the student survey data of PISA 2018 assessment and probable science values calculated for each student, the determining role of students' level of interest in environmental problems on students' science literacy was examined. Whether the findings obtained are statistically significant were analysed and similarities and differences in countries and economies were examined. It can be stated that this study provides scientific evidence that students' interest in environmental problems is a determining factor in science literacy. It can be said that these results have similarities for 15 countries and economies within the scope of the study.

First, the t-test results show that there are significant differences between the science literacy scores of students who are very interested in environmental issues and that of those who are not interested. In other words, students who are very interested in environmental problems in their country and other countries have higher science literacy scores than students who are not interested at all. It can be stated that this result is consistent with other 
studies in the literature (Areepattamannil \& Kaur, 2013; Kilic Depren, 2018; Thomson \& De Bortoli, 2008). In these studies, researchers have suggested that students' science literacy may increase and develop when they are interested in environmental problems. It can be said that it is remarkable to develop policies and strategies to increase participation and interest in environmental activities, as the results of this study confirm that students' interest in environmental problems affects science literacy. Encouraging students to be interested in environmental issues can lead to significant improvements in their science literacy performance.

\section{Figure 3.}

ANN Model Structure for Students' Interest Status of Environmental Issues in Other Country on Science Literacy Scores

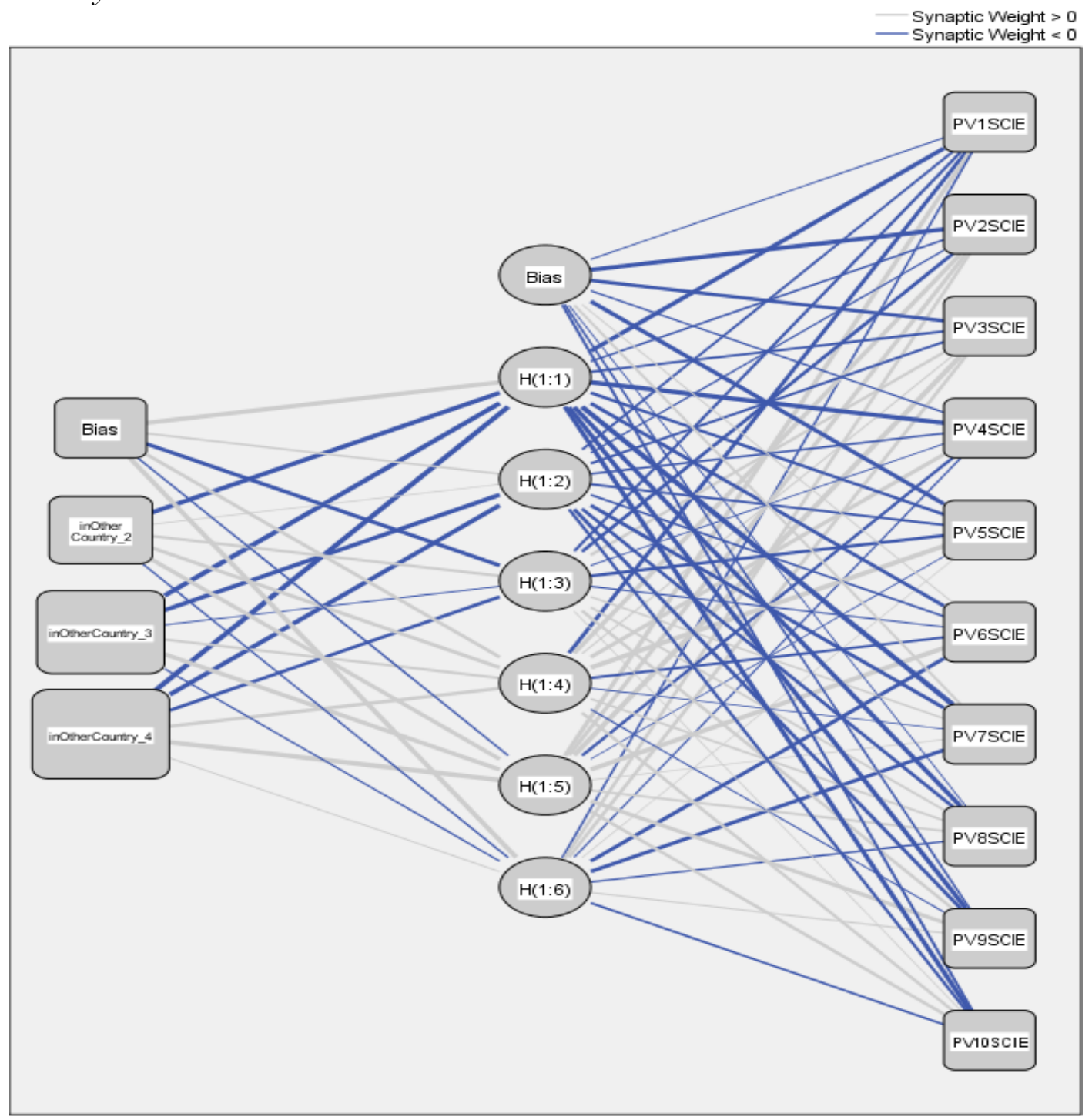

Secondly, multiple linear regression and ANN analysis results have shown that the increase of students' interest in environmental problems positively contributes to their science literacy scores. This result is also important to highlight the link between science literacy and environmental issues. The link between science literacy and awareness of 
environmental issues has not yet been studied adequately (Boeve-de Pauw et al., 2010), but the results of this study can be said to increase our knowledge of this topic, emphasizing the strong link between relevance to environmental issues and science literacy.

Table 9.

The Importance Ratings of Independent Variables (Students' Interest Status of Environmental Issues in Other Country) Related to Students' Science Literacy Scores

\begin{tabular}{lll}
\hline & Importance & Normalized Importance \\
\hline Not very interested & .250 & $63 \%$ \\
Somewhat interested & .354 & $89.4 \%$ \\
Very interested & .396 & $100 \%$ \\
\hline
\end{tabular}

According to the findings, although regression analysis showed a statistically significant relationship $(\mathrm{p}<.01)$, the amount of variation explained was very low $\left(\mathrm{R}^{2}=0.3 \%\right)$. $\mathrm{R}^{2}$ alone does not reflect the entire picture with respect the efficiency of a sample regression curve; consequently, for large sample size as PISA 2018, the small $\mathrm{R}^{2}$ value is statistically significant (Günel, 2003). Therefore, two variables that play role concerning science literacy are student interestedness of environmental issues in both home and other countries. It is not surprising that promoting students' interestedness of environmental issues can lead to significant improvements in performance in science subjects. One of the five science and technology applications in which the contex ts of the contexts in the PISA science assessment are categorized is environmental quality, and the topics covered by environmental quality are environmentally friendly actions, use and disposal of materials and devices, disposal of waste, environmental impact biodiversity, ecological sustainability, control of pollution, production and loss of soil / biomass (OECD, 2019a). Thus, students who are interested in environmental issues may have increased their science scores by answering the relevant items correctly due to their familiarity with this content.

In fact, multiple linear regression and $\mathrm{ANN}$ analysis results show that students' being relevant to environmental issues to a degree is enough to increase their science literacy scores. Similar to this result, Alivernini \& Manganelli's (2015) study covering 25 countries has shown that students with a lower level of environmental awareness have a very low success rate in science literacy, while students who tend to have a higher level of environmental awareness are the best performers. Considering that science subjects are taught in a more practical way in schools where there are students with higher environmental awareness (Boeve-de Pauw et al., 2010), schools may need to increase measures to enhance students' interest in environmental issues.

It has been shown in various studies that students' family and school characteristics, social interactions, epistemic beliefs affect their interest in environmental issues (Duarte et al., 2017; Lin \& Shi, 2014; Susongko, \& Afrizal, 2018). Considering these findings together with the results of this study, it can be argued that content and processes related to environmental issues should be integrated into daily life and education programs in order to increase and support students' science literacy.

One of the limitations of this research is the measurement of the complex structures that Singh et al., (2002) also emphasize in their study. Being interested in environmental problems is a complex variable that is difficult to determine with high reliability and validity. Even if there are precautions against this in the design and implementation of PISA 2018, the low number of questions, from which data on independent variables are obtained, can limit the reliable and valid measurement of predictive factors. Despite this limitation, it can 
be said that the fact that all analysis results are statistically significant and their effect sizes are high supports the robustness of the theoretical model that shows the importance of these predictive variables in science literacy. In this context, future research should include variables that further explain students' interest in environmental issues. Moreover, more scientific evidence is needed on the effects of interest in environmental issues on science literacy, and analysis with alternative research designs can provide more accurate evidence about this matter. In this context, qualitative methods can help understanding how students are really interested in environmental issues and identifying factors predicting science literacy.

In summary, in this study, where the role of relevance of students in 15 different countries and economies to environmental issues on science literacy was analysed, it was found that in general, being related to environmental problems had positive and important effects for science literacy, and the findings in this study are consistent with the current literature. This result is of great importance for policy makers, and the effects of interest in the environment can serve to establish policies to increase and improve science literacy, which has an important role in making countries have a voice in the international arena. In addition, the results of the research show that the students' interest in environmental problems both in their own country and in other countries increases science literacy. For this reason, this research emphasizes the importance of students' being concerned with environmental problems, and underlines that the ways, which increase the environmental awareness of families, teachers and school administrators, should be taken into consideration.

\section{Notes}

1. While calculating the effect size, Cohen's $d=(\mathrm{M} 2-\mathrm{M} 1) / \mathrm{SD}_{\text {pooled }} \& \mathrm{SD}_{\text {pooled }}=$ $\sqrt{ }\left(\left(\mathrm{SD}_{1}{ }^{2}+\mathrm{SD}_{2}{ }^{2}\right) / 2\right)$ formulas were used.

2. In 15 countries and economies within the scope of the study, it was also examined whether there was a significant difference between the science literacy scores of the students who answered "not interested at all" and "very interested" and students who answered "not very interested" and "somewhat interested" to the survey questions. The differences and impact levels are very similar and are available upon request..

\section{References}

Alivernini, F., \& Manganelli, S. (2015). Country, school and students factors associated with extreme levels of science literacy across 25 countries. International Journal of Science Education, 37(12), 1992-2012. http://dx.doi.org/10.1080/09500693.2015.1060648

Allison, P. D. (2002). Missing data. Sage Publications, Inc.

Areepattamannil, S., \& Kaur, B. (2013). Factors predicting science achievement of immigrant and non-immigrant students: A multilevel analysis. International Journal of Science and Mathematics Education, 11 (5), 1183-1207.

https://doi.org/10.1007/s10763-012-9369-5

Boeve-de Pauw, J., Coertjens, L., De Maeyer, S., \& Van Petegem P. (2010). Do schools make a difference in their students' environmental attitudes and awareness? evidence from PISA 2006. In G. Cakmakci \& M.F. Taşar (Eds.), Contemporary science education research: Scientific literacy and social aspects of science (pp. 231-250). Pegem Akademi.

Bybee, R. W. (2008). Scientific literacy, environmental issues, and PISA 2006: The 2008 Paul F-Brandwein lecture. Journal of Science Education and Technology, 17(6), 566585. https://doi.org/10.1007/s 10956-008-9124-4 
Cohen, J. (1988). Statistical power analysis for the behavioral sciences (2nd ed.). Lawrence Earlbaum Associates.

Corti, L. (2008). Secondary analysis. In L. M. Given (Ed.), The Sage encyclopedia of qualitative research methods volumes $1 \Xi^{2} 2$ (pp. 801-803). SAGE Publications, Inc.

Duarte, R., Escario, J. J., \& Sanagustín, M. V. (2017). The influence of the family, the school, and the group on the environmental attitudes of European students. Environmental Education Research, 23(1), 23-42. https://doi.org/10.1080/13504622.2015.1074660

Günel, A. (2003). Some critics on the use of coefficient of determination as a significance test criterion for regression equation. Dogus University Journal, 4(2), 133-140.

Holbrook, J., \& Rannikmae, M. (2009). The meaning of scientific literacy. International Journal of Environmental and Science Education, 4(3), 275-288.

Johnston, M. P. (2017). Secondary data analysis: A method of which the time has come. Qualitative and Quantitative Methods in Libraries, 3(3), 619-626.

Kaya, V. H., \& Elster, D. (2018). German students' environmental literacy in science education based on PISA data. Science Education International, 29(2), 75-87.

Kilic Depren, S. (2018). Prediction of students' science achievement: An application of multivariate adaptive regression splines and regression trees. Journal of Baltic Science Education, 17(5), 887-903. http://dx.doi.org/10.33225/jbse/18.17.887

Kim, J. H. (2019). Multicollinearity and misleading statistical results. Korean Journal of Anesthesiology, 72(6), 558-569. https://doi.org/10.4097/kja.19087

Lin, E., \& Shi, Q. (2014). Exploring individual and school-related factors and environmental literacy: Comparing US and Canada using PISA 2006. International Journal of Science and Mathematics Education, 12(1), 73-97. https://doi.org/10.1007/s10763-012-9396$\underline{\underline{2}}$

Littledyke, M. (2008). Science education for environmental awareness: approaches to integrating cognitive and affective domains. Environmental Education Research, 14(1), 1-17. https://doi.org/10.1080/13504620701843301

Lumley, T., Diehr, P., Emerson, S., \& Chen, L. (2002). The importance of the normality assumption in large public health data sets. Annual review of public health, 23(1), 151169. https://doi.org/10.1146/annurev.publhealth.23.100901.140546

Ma, Y., \& Qin, X. (2021). Measurement invariance of information, communication and technology (ICT) engagement and its relationship with student academic literacy: Evidence from PISA 2018. Studies in Educational Evaluation, 68. https://doi.org/10.1016/j.stueduc.2021.100982

McGinn, K. (2008). Secondary data. In L. M. Given (Ed.), The Sage encyclopedia of qualitative research methods volumes 1 छ2 (pp. 803-804). SAGE Publications, Inc.

Midi, H., Sarkar, S. K., \& Rana, S. (2010). Collinearity diagnostics of binary logistic regression model. Journal of Interdisciplinary Mathematics, 13(3), 253-267. https://doi.org/10.1080/09720502.2010.10700699

Mirazchiyski, P. (2014). Analyzing the TALIS data using the IEA IDB Analyzer. In A. Becker (Ed.), TALIS user guide for the international database (pp. 28-72). OECD Publishing.

OECD. (2006). Assessing scientific, reading and mathematical literacy: A framework for PISA 2006. OECD Publishing. https://doi.org/10.1787/9789264026407-en

OECD. (2009). PISA data analysis manual: SPSS (2nd Ed.). OECD Publishing. https://doi.org/10.1787/9789264056275-en

OECD. (2013). PISA 2015 integrated design. OECD Publishing. https://www.oecd.org/pisa/pisaproducts/2015-Integrated-Design.pdf 
OECD. (2016). PISA 2015 results (volume I): Excellence and equity in education. OECD Publishing. http://dx.doi.org/10.1787/9789264266490-en

OECD. (2017). PISA 2015 technical report. OECD Publishing. https://www.oecd.org/pisa/data/2015-technical-report/

OECD. (2019a). PISA 2018 assessment and analytical framework. OECD Publishing. https://doi.org/10.1787/b25efab8-en

OECD. (2019b). PISA 2018 results (volume I): What students know and can do. OECD Publishing. https://doi.org/10.1787/5fo7c754-en

Rutkowski, L., Gonzalez, E., Joncas, M., \& von Davier, M. (2010). International large-scale assessment data: Issues in secondary analysis and reporting. Educational Researcher, 39(2), 142-151. https://doi.org/10.3102\%2F0013189X10363170

Sadler, T. D., \& Zeidler, D. L. (2009). Scientific literacy, PISA, and socioscientific discourse: Assessment for progressive aims of science education. Journal of Research in Science Teaching, 46(8), 909-921. https://doi.org/10.1002/tea.20327

Schneider, S. H. (1997). Defining and teaching environmental literacy. Trends in Ecology \& Evolution, 12(1 1), 457. https://doi.org/10.1016/s0169-5347(97)01207-x

Shatskikh, S. Y., \& Melkumova, L. E. (2016). Normality assumption in statistical data analysis. Proceedings of International Conference Information Technology and Nanotechnology (ITNT-2016). https://doi.org/10.18287/1613-0073-2016-1638-763$\underline{768}$

Sherif, V. (2018). Evaluating preexisting qualitative research data for secondary analysis. Forum: Qualitative Social Research, 19(2), 26-42. https://doi.org/10.17169/fqs19.2.2821

Singh, K., Granville, M., \& Dika, S. (2002). Mathematics and science achievement: Effects of motivation, interest, and academic engagement. The Journal of Educational Research, 95(6), 323-332. https://doi.org/10.1080/00220670209596607

Susongko, P., \& Afrizal, T. (2018). The determinant factors analysis of Indonesian students' environmental awareness in PISA 2015. Jurnal Pendidikan IPA Indonesia, 7(4), 407419.

Thomson, S. \& De Bortoli, L. (2008). Exploring scientific literacy: How Australia measures up: The PISA 2006 survey of students' scientific, reading and mathematical literacy skills. ACER.

Thomson, S., De Bortoli, L., Underwood, C., \& Schmid, M. (2019). PISA 201 8: Reporting Australia's results. Volume I student performance. ACER.

Turner, P. D. (1997, March). Secondary analysis of qualitative data. Annual Meeting of the American Educational Research Association, Chicago, IL. https://files.eric.ed.gov/fulltext/ED412231.pdf

Wilson, E. O. (2002). The future of life. Alfred A. Knopf.

\section{About the Author}

Umut Birkan Özkan is head of the Educational Sciences Department at the National Defence University Army NCO Vocational College, Turkey. He has 21 years teaching experience at various levels, from high school to university. Dr. Özkan received his Ph.D. degree in the field of Curriculum and Instruction in 2016. His academic interest areas are curriculum studies, teacher education, instructional design, academic achievement, large scale assessments, and instructional technologies. He has three books, two book chapters, and more than 20 journal articles published in international and national indexes, and many papers presented at international meetings. 